\title{
Cationic Surfactants: Potential Surface Disinfectants to Manage Agrobacterium tumefaciens Biovar 1 Contamination of Grafting Tools
}

\author{
L. E. Yakabe, S. R. Parker, and D. A. Kluepfel, United States Department of Agriculture-Agricultural Research Service Crops \\ Pathology and Genetics Research Unit, Davis, CA
} \begin{abstract}
biovar 1 contamination of grafting tools. Plant Dis. 96:409-415.
Nursery production of walnut seedlings is a 2-year process, during which crown gall, caused by Agrobacterium tumefaciens, often develops at grafting wounds. In this study, the spread of crown gall via contaminated tools and the efficacy of several disinfectants against $A$. tumefaciens were demonstrated. The cationic surfactants benzalkonium chloride (BC), cetyltrimethylammonium bromide (CTAB), and Physan 20 eliminated $100 \%$ of the A. tumefaciens population in water suspensions treated at 7, 5, and $2 \mathrm{ppm}$, respectively. Sodium hypochlorite eliminated $100 \%$ of the A. tumefaciens population at $0.5 \mathrm{ppm}$. Sodium hypochlorite efficacy, however, was reduced by $64 \%$ in the presence of
\end{abstract}

Abstract

Yakabe, L. E., Parker, S. R., and Kluepfel, D. A. 2012. Cationic surfactants: Potential surface disinfectants to manage Agrobacterium tumefaciens

total solids $(0.7 \mathrm{~g} / \mathrm{ml})$ which are commonly found in field situations. At similar concentrations of total solids, the efficacy of cationic surfactants decreased, on average, by only $13 \%$. The minimum effective treatment needed to eliminate $A$. tumefaciens on infested scalpels was a 5 -s exposure to $\mathrm{BC}$ or $\mathrm{CTAB}$ at 5,000 ppm (0.5\%). Infested scalpels treated with $\mathrm{BC}$ or $\mathrm{CTAB}$ at less than 5,000 ppm caused gall formation in $14 \pm 7 \%$ of cuts made on Datura stramonium stems. This was significantly less than the tumor incidence $(100 \%)$ in cuts made with inoculated blades not treated $\mathrm{BC}$ or CTAB.
Since the 1970s, the walnut hybrid Juglans regia L. $\times$ J. hindsii Jeps. ex R.E. Sm. 'Paradox' has been the dominant rootstock used in California walnut production (34). Paradox induces precocity and vigorous scion growth while providing variable resistance to several species of Phytophthora and tolerance to low populations of Pratylenchus vulnus $(11,31,32)$. Unfortunately, Paradox is highly susceptible to Agrobacterium tumefaciens Smith and Townsend, the causal agent of crown gall $(31,32)$.

In nursery production of walnut trees, English walnut (J. regia) scions are grafted onto 1-year-old Paradox seedlings, which are sold to walnut growers 10 to 12 months later (34). This 2-year process involves cutting the seedlings several times in the field. First, the English walnut scion is grafted onto a Paradox rootstock and the union is wrapped. Second, several "bleeding" cuts are often made below the graft union to reduce xylem turgor pressure, which can separate the scion from the rootstock before the graft has healed. All these plant wounds can serve as sites for A. tumefaciens infection via windblown dust, tools contaminated by soil, or cutting through stems systemically infected with populations of $A$. tumefaciens, as demonstrated for crops like chrysanthemum $(17,27)$. Crown gall symptoms have frequently been observed at wound sites incurred during the grafting process in nurseries in California (L. Yakabe, personal observation).

The importance of grafting tool sanitation has been demonstrated for numerous crops in which plant pathogens are readily transferred from plant to plant via grafting tools (2). Several studies have documented $A$. tumefaciens-contaminated tools contributed to gall formation at the cut wounds in rose and chrysanthe-

Corresponding author: D. A. Kluepfel,

E-mail: Daniel.Kluepfel@ars.usda.gov

* The $\boldsymbol{e}$-Xtra logo stands for "electronic extra" and indicates that one supplemental table and one supplemental figure are available online.

Accepted for publication 19 October 2011.

http://dx.doi.org/10.1094/PDIS-11-10-0839

This article is in the public domain and not copyrightable. It may be freely reprinted with customary crediting of the source. The American Phytopathological Society, 2012. mum production $(17,27,32)$. The sanitation of tools between sequential cuts is an important first step in crown gall management in numerous crop production systems, including the walnutpropagation industry.

Sodium hypochlorite, a standard sanitizing agent in many industries, is an effective disinfectant of water and solid surfaces. However, it is corrosive and is rapidly inactivated by dissolved or suspended solids such as organic matter, which is common in field situations $(15,16,44)$. Surfactants offer potentially effective alternatives to sodium hypochlorite for the control of microorganisms in environments with high levels of organic matter. Surfactants are commonly used in household products such as dishwashing detergents and shampoos, as agricultural wetting agents, and as disinfectants in the food industry and medical fields $(20,26,35,36)$ Surfactants reduce surface tension at the interface between hydrophilic and hydrophobic molecules. The amphipathic nature of surfactants also alters the structure and function of cellular membranes, including modifying enzyme activity and affecting cell lysis $(8,9,25)$. Numerous studies have reported on the ability of surfactants to disinfect solid surfaces $(3,12,13,20,23,30,36,41,42)$. Surfactants also have been used to manage oomycete plant pathogens in water used for hydroponic cultivation of lettuce and pepper (37).

There are four main classes of surfactants used as disinfectants: nonionic, amphoteric, anionic, and cationic $(8,9)$. In general, cationic surfactants exhibit the greatest degree of antimicrobial activity, while nonionic surfactants show the least activity. In fact, Rajagopal et al. (33) reported Gram-negative bacteria were 10,000 times more sensitive to cationic detergents than anionic detergents. However, in that study, the examination of cationic surfactant antimicrobial activity was restricted to members of the family Enterobacteriaceae. A. tumefaciens, a member of the family Rhizobiaceae, is hypothesized to respond similarly. Reported in this study are investigations into the potential role of grafting tools in the spread of crown gall, and the utility of sodium hypochlorite and several surfactants as grafting tool disinfectants to manage crown gall in the production of grafted walnut seedlings.

\section{Materials and Methods}

Bacterial characterization and inoculum preparation. A. tumefaciens isolate 186, originally isolated from a stem section of a walnut seedling in Stanislaus County, CA, was used to generate 
dose response curves to the compounds examined in this study. Identification of the isolate was accomplished through 16S rDNA sequencing using universal primers fd6 and $\mathrm{rp5}$ (43). A positive Benedict's test confirmed identification of the isolate as $A$. tumefaciens biovar 1 (29). To facilitate recovery of the isolate from complex environments, a rifampicin-resistant mutant of A. tumefaciens 186, 186r, was generated by growing isolate 186 on trypticase soy broth agar (TSBA) amended with rifampicin sulfate at $100 \mathrm{ppm}$ (TSBA + rif) for 3 days at $28^{\circ} \mathrm{C}$. Rifampicin-resistant colonies were picked and streaked onto TSBA + rif and incubated at $28^{\circ} \mathrm{C}$ for $48 \mathrm{~h}$. Single colonies were picked and confirmed to be rifampicin-resistant derivatives of A. tumefaciens 186 using $16 \mathrm{~S}$ rDNA sequence alignment comparisons with the wild-type parent isolate. A. tumefaciens 186r was used in experiments examining transmission via plant wounding, tool disinfestation, and effect of total solids on antimicrobial efficacy of the compounds tested.

Antibiotic-resistance profiles were assessed by swabbing 186r and the wild-type isolate 186 onto the surface of TSBA. Immediately after streaking, antibiotic disks (Sensi-disk; Becton, Dickson and Co., Sparks, MD) treated with chloramphenicol $(30 \mu \mathrm{g})$, ampicillin $(10 \mu \mathrm{g})$, nalidixic acid $(30 \mu \mathrm{g})$, minocycline $(30 \mu \mathrm{g})$, trimethoprim $(5 \mu \mathrm{g})$, bacitracin $(10 \mu \mathrm{g})$, tobramycin $(10 \mu \mathrm{g})$, kanamycin $(30 \mu \mathrm{g})$, cefoperazone $(75 \mu \mathrm{g})$, or rifampicin $(5 \mu \mathrm{g})$ were placed on the agar surface. Inoculated TSBA plates were incubated at $28^{\circ} \mathrm{C}$ for $48 \mathrm{~h}$, after which the diameter of the zone of growth inhibition of the bacterium by each antibiotic was measured. Each isolate was tested in triplicate in each of two trials in a completely randomized design. Data for the zones of inhibition were subject to an analysis of variance (ANOVA) using PROC GLM in SAS (version 9.1; SAS Institute, Cary, NC).

Growth rates of isolates 186 and 186r were also examined in 25$\mathrm{ml}$ aliquots of $\mathrm{AB}$ liquid medium (6) shaken at $200 \mathrm{rpm}$ and incubated at $28^{\circ} \mathrm{C}$. Growth-curve cultures were adjusted to an initial optical density at $600 \mathrm{~nm}\left(\mathrm{OD}_{600}\right)$ of 0.025 using bacterial cells grown in $\mathrm{AB}$ liquid medium for $48 \mathrm{~h}$. Growth was evaluated spectrophotometrically $\left(\mathrm{OD}_{600}\right)$ every $2.5 \mathrm{~h}$ for the first $10 \mathrm{~h}$ followed by measurements every $4 \mathrm{~h}$ for the next $44 \mathrm{~h}$. Cultures were arranged in a completely randomized design in the incubator. Two growth-curve trials were conducted with each isolate replicated in triplicate.

The ability of 186 and 186r to cause galls was tested on Datura stramonium, a susceptible host of A. tumefaciens. Fourteen-day-old seedlings were wounded on the stem with a straight-edge razor. The wounds were immediately inoculated with $1 \mu \mathrm{l}$ of a 48 -h culture of either 186 or 186r, and subsequently wrapped with Parafilm (Pechiney Plastic Packaging Company, Chicago, IL). Plants were incubated in a completely randomized design in a greenhouse for 2 weeks, after which gall formation was recorded. Each isolate was inoculated onto three plants in each of two trials.

A. tumefaciens inoculum was prepared by adding a 3- $\mu$ l loop of a 48 -h culture of 186 grown on TSBA or 186r grown on TSBA + rif to $3 \mathrm{ml}$ of trypticase soy broth. The cultures were incubated at $28^{\circ} \mathrm{C}$ on a rotary shaker $(200 \mathrm{rpm})$ for $48 \mathrm{~h}$. Each bacterial suspension was centrifuged at $5,468 \times g$ for $10 \mathrm{~min}$. The resulting pellet was washed twice using sterile distilled water and resuspended in sterile distilled water. The inoculum suspension was then adjusted spectrophotometrically to approximately $10^{8} \mathrm{CFU} / \mathrm{ml}\left(\mathrm{OD}_{600}=0.1\right)$.

Cutting tool transmission assay. To assess whether A. tumefaciens can be harbored on and transmitted by cutting or grafting tools, D. stramonium, a crown gall indicator plant, and Paradox hybrid walnut plants were cut with scalpel blades (number 11 stainless-steel surgical blades; Miltex Inc., York, PA) dipped in either a suspension of A. tumefaciens 186r or sterile water. After a single dip in the inoculum or water, the scalpel was used to inoculate $10 \mathrm{D}$. stramonium plants in succession. Each cutting wound was wrapped immediately with Parafilm and the plants were incubated for approximately 30 days in a greenhouse, after which incidence of cuts with galls was recorded. Plants were treated and arranged in a greenhouse in a completely randomized design. In a separate experiment, Paradox walnuts seedlings were cut acro- petally along the length of the stem six consecutive times after the grafting knife (Victorinox, Ibach-Schwyz, Switzerland) was dipped once in a suspension of $A$. tumefaciens $186 \mathrm{r}$ or water. Wounds were wrapped immediately with Parafilm. Plants were treated and arranged in a greenhouse in a completely randomized design. Gall development was recorded after 60 days. To allow symptom development from latent infections and examine the effects of plant dormancy on gall incidence, the walnut plants were incubated at $6^{\circ} \mathrm{C}$ in the dark for 120 days to induce dormancy after the initial 60 -day observation time. Gall development was recorded 60 days after plants emerged from dormancy.

For each host plant experiment, the treatments were repeated six times in each of two trials. Trial was not a significant factor affecting the frequency of gall development on $D$. stramonium or Paradox within each treatment, as determined by $\chi^{2}$ analysis (at $P \leq$ 0.05 ) (38). Therefore, data from the two trials were pooled for each host. The total frequencies of gall development using inoculated versus noninoculated blades was subject to $\chi^{2}$ analysis $(P \leq 0.05)$. To represent the data in terms of the percentage of plants that developed galls, data for the six replicates were randomly pooled into groups of three replicates. Results for the percentage of plants that developed galls were subjected to an ANOVA using PROC GLM in SAS. When necessary, data were transformed using a log transformation or PROC RANK in SAS to meet the assumptions of ANOVA. Means separation was accomplished using Tukey's $w$ test calculated in SAS (38).

Surfactants. Cationic surfactants tested were benzalkonium chloride (BC; Sigma-Aldrich, St. Louis), cetyltrimethylammonium bromide (CTAB; Sigma-Aldrich), and Physan 20 (Maril Products Incorporated, Tustin, CA), the latter registered for tool disinfection in the United States. The non-ionic surfactants tested were TritonX (Lab Chem Inc., Pittsburgh, PA), Tween 20 (Promega Corp., Madison, WI), and Nonidet P40 (Fluka BioChemica, Buchs, Switzerland). The anionic surfactants tested were sodium laural sarcosine (EMD, Darmstadt, Germany), sodium cholate hydrate (Sigma-Aldrich), sodium dodecyl sulfate (EMD), and taurocholic acid (ICN Biomedicals Inc., Aurora, OH).

Surfactant antimicrobial screening. A. tumefaciens $186(20 \mu \mathrm{l}$, $\mathrm{OD}_{600}=0.1$ ) was exposed to $180 \mu \mathrm{l}$ of each surfactant at final concentrations of $10^{2}, 10^{3}$, and $10^{4} \mathrm{ppm}$ in a covered, 96-well plate. The nontreated control treatment consisted of a $20-\mu$ l aliquot of isolate 186 placed in $180 \mu \mathrm{l}$ of sterile, deionized water. The surfactant-bacterial suspensions were incubated for $30 \mathrm{~min}$ at room temperature (approximately $25^{\circ} \mathrm{C}$ ) and then serially diluted on TSBA. Dilution plates were placed in an incubator in a completely randomized design for $36 \mathrm{~h}$ at $28^{\circ} \mathrm{C}$ before enumerating bacterial colonies. Three replicates were included for each surfactant at each concentration. Data were transformed to meet the assumptions of ANOVA by ranking using PROC RANK in SAS, and then subjected to ANOVA using PROC GLM. Given that CTAB and BC were the most effective at reducing bacterial populations (Table 1), these surfactants were selected for further testing.

Evaluation of BC, CTAB, Physan 20, and sodium hypochlorite. Assays used to generate dose response curves for $\mathrm{BC}, \mathrm{CTAB}$, Physan 20 (Physan), and sodium hypochlorite on A. tumefaciens 186 were conducted in covered 96-well plates as described above at concentrations of 0.5 to $100 \mathrm{ppm}$. The negative control treatment consisted of isolate 186 incubated in water. Each disinfectant concentration was replicated four times in each of two trials in a randomized complete block design. Trial was not a significant factor at any of the concentrations tested as determined by ANOVA $(P \leq$ $0.05)$ using PROC GLM and, thus, data from both trials were pooled. The lethal dose required to eliminate $100 \%$ of the bacterial population $\left(\mathrm{LD}_{100}\right)$ was determined for each product based on the minimum concentration of disinfectant in which all replicate plates of the treatment yielded no recoverable bacteria.

Exposure time assays. In $1.5-\mathrm{ml}$ microcentrifuge tubes, $50-\mu \mathrm{l}$ aliquots of A. tumefaciens 186 were added to $450 \mu \mathrm{l}$ of $\mathrm{BC}$ or $\mathrm{CTAB}$ at $70,100,500$, or $5,000 \mathrm{ppm}$. The resulting suspensions were incubated for $1,5,10,20$, or $30 \mathrm{~s}$ to determine the effect of 
exposure time on survival of the bacterium. To determine surviving populations of A. tumefaciens $186,500 \mu \mathrm{l}$ of each solution was serially diluted and plated on TBSA. After incubation in a completely randomized design for $36 \mathrm{~h}$ at $28^{\circ} \mathrm{C}$, colonies were enumerated. Each surfactant concentration at each exposure time was replicated four times in each of two trials. Data were transformed to meet the assumptions of ANOVA using PROC RANK in SAS and then subjected to ANOVA using PROC GLM. The main effect of trial and interaction terms of trial with surfactants, surfactant concentration, and duration of exposure were not significant in the ANOVA $(P>0.05)$, thus data from both trials were pooled. The pooled ANOVA determined the interaction between surfactant concentration and duration of exposure was significant $(P=0.004)$; hence, means separation using Tukey's $w$ test was calculated for all surfactant concentration and exposure time-treatment combinations.

Greenhouse cutting tool assays. To determine the efficacy of $\mathrm{BC}$ and $\mathrm{CTAB}$ for disinfecting grafting tools, noninoculated or $A$. tumefaciens $186 \mathrm{r}$-inoculated scalpels were dipped in $\mathrm{BC}$ or CTAB at 70,100,500, or 5,000 ppm or sterile water, or not dipped, before sequentially cutting D. stramonium stems. D. stramonium was chosen for these assays because this indicator plant is more susceptible to A. tumefaciens infection than walnut and is known to produce symptoms reliably a few weeks after infection compared with walnut, which can require 4 weeks to several years for symptom development. Only the cutting edge of the blade was inoculated with $A$. tumefaciens 186r. The bacterial suspension was placed on a glass slide into which the cutting edge of the blade was dipped. The blade was then agitated in $5 \mathrm{ml}$ of the appropriate disinfectant solution for $5 \mathrm{~s}$, followed by a quick flick of the blade to remove excess solution. D. stramonium plants then were each cut once with the treated blade. To quantify the number of bacteria remaining on the blade after the cut, the blade was removed from the scalpel and submerged in $5 \mathrm{ml}$ of sterile water for $10 \mathrm{~min}$, after which the water was diluted serially and plated on TSBA + rif medium. The number of bacteria in the used disinfectant solution also were enumerated by dilution plating onto TSBA + rif medium. All dilution plates were incubated for $48 \mathrm{~h}$ at $28^{\circ} \mathrm{C}$, after which colonies were enumerated. D. stramonium plants were arranged in a completely randomized design in a greenhouse. Gall development was evaluated after 30 days. Each treatment was replicated six times in each of two trials. Differences in the numbers of CFU detected on blades and in the disinfectant solutions were analyzed by ANOVA using PROC GLM in SAS. The fre- quency of gall development recorded for each of the disinfectant treatments was compared with that of the sterile water control treatment using a $\chi^{2}$ analysis with a Bonferroni adjusted significance of $P \leq 0.00625$ (28).

Effect of total solids on disinfectant efficacy. To generate a disinfectant solution with a high concentration of total solids, $1,500 \mathrm{~cm}^{3}$ of peat moss was steeped in 3 liters of deionized water for 7 days. After the suspension was filtered through four layers of cheesecloth to remove large particles, calcium carbonate was added to adjust the suspension to $\mathrm{pH}$ 7.0. Total solids of this peatamended suspension were determined by the University of California Agriculture and Natural Resources Analytical Lab (Davis, CA). The peat-amended suspension then was mixed with deionized water to produce suspensions with total solids at $0.7,1.5,2.0$, and $3.0 \mathrm{~g} / \mathrm{ml}$. These suspensions were used to create BC, CTAB, Physan, and sodium hypochlorite solutions containing lethal doses that killed $80 \%$ of the bacterial population $\left(\mathrm{LD}_{80}\right)$. $\mathrm{LD}_{80}$ concentrations were first estimated from a linear regression of the linear phase of the dose response curves described above, and adjusted based on preliminary experiments (data not shown). Linear regressions were performed using PROC REG in SAS. Tested in the same 96-well plate assay as described above, $180 \mu \mathrm{l}$ of each of the peat-amended BC, CTAB, Physan, and sodium hypochlorite solutions were added to $20-\mu$ l suspensions of $A$. tumefaciens $186 \mathrm{r}\left(\mathrm{OD}_{600}=0.1\right)$, and incubated at room temperature (approximately $23^{\circ} \mathrm{C}$ ) for $30 \mathrm{~min}$. The peat-amended surfactant suspensions were made no more than $1 \mathrm{~min}$ prior to the addition of the bacterial suspension. Bacterial survival was determined as described above. The negative control treatment consisted of $A$. tumefaciens 186r incubated in peat-amended water for $30 \mathrm{~min}$. Each treatment was replicated three times in each of two trials. The differences in efficacy between disinfectant solutions prepared in water versus peat-amended water were evaluated by ANOVA using PROC GLM.

\section{Results}

Comparison of A. tumefaciens isolates 186 and 186r. Except for growth in the presence of rifampicin, the rifampicin-resistant strain of A. tumefaciens, 186r, was indistinguishable from the wildtype parent, A. tumefaciens 186 (Supplementary Table S1). The growth rate of 186r was also within the $95 \%$ confidence interval of the growth rate of 186 (Supplementary Figure S1). Both isolates also caused gall formation on D. stramonium (data not shown).

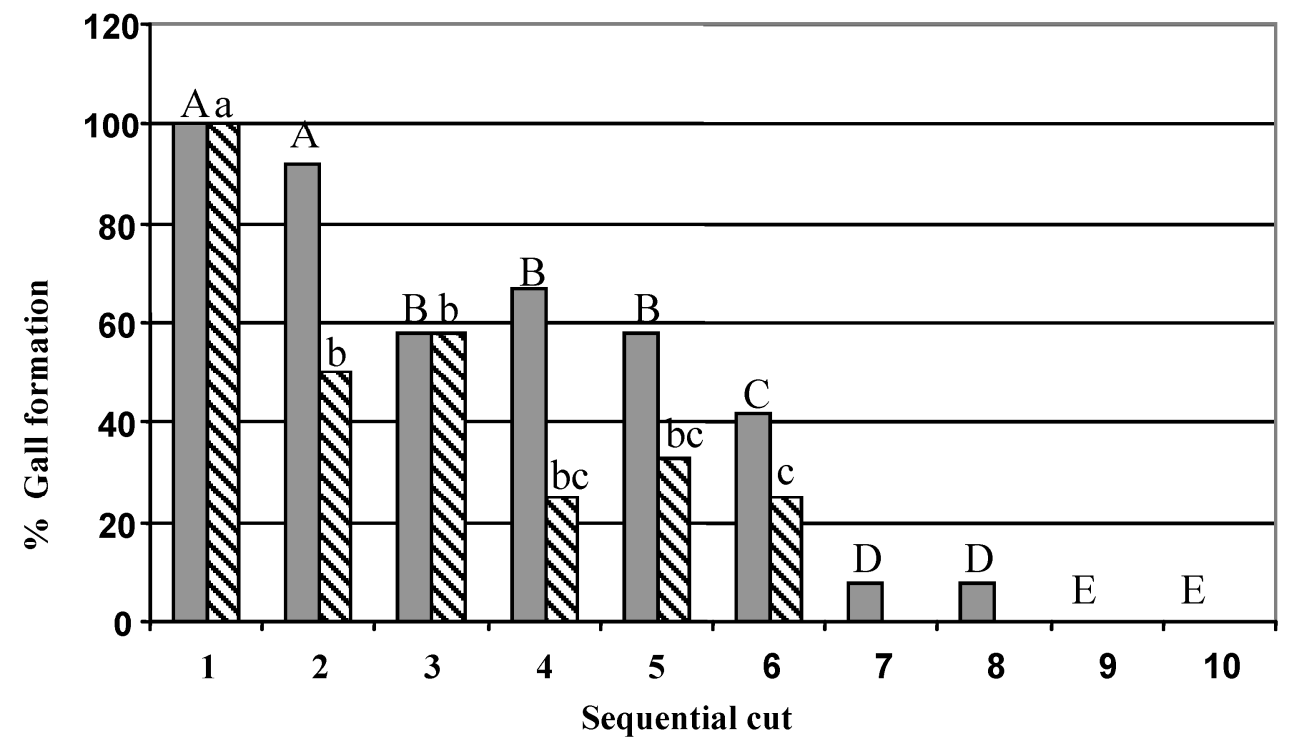

Fig. 1. Incidence of crown gall from sequential cuts made on Datura stramonium (solid bars) and 'Paradox' walnut seedlings (hatched bars) using a cutting tool inoculated with Agrobacterium tumefaciens. Ten sequential cuts were made on $D$. stramonium versus six on walnut seedlings. Different letters within each plant type indicate statistically significant differences as determined by Tukey's w procedure for means separation. Plants cut with noninoculated blades (control treatment) did not develop galls. Each treatment was replicated six times in two trials. Data from both trials were pooled. 
Cutting tool transmission. Wounding plants with cutting tools infested with A. tumefaciens $186 \mathrm{r}$ caused crown gall development on D. stramonium and Paradox walnut plants. Each inoculated blade caused the formation of at least one gall on the set of cut

Table 1. Reduction of Agrobacterium tumefaciens populations after $30 \mathrm{~min}$ of exposure to selected surfactants

\begin{tabular}{lcc}
\hline Class, surfactant & $\begin{array}{c}\text { Surfactant } \\
\text { concentration }(\mathbf{p p m})\end{array}$ & $\begin{array}{c}\text { Reduction } \\
(\boldsymbol{\%})^{\mathbf{y}}\end{array}$ \\
\hline Nonionic & 10,000 & $100 \mathrm{ab}$ \\
Triton X & 1,000 & $100 \mathrm{ab}$ \\
& 100 & $97 \mathrm{bcd}$ \\
Nonidet P40 & 10,000 & $93 \mathrm{bcde}$ \\
& 1,000 & $92 \mathrm{cdef}$ \\
Tween 20 & 100 & $89 \mathrm{efg}$ \\
& 10,000 & $96 \mathrm{bcd}$ \\
Anionic & 1,000 & $92 \mathrm{cdef}$ \\
Sodium dodecyl sulfate & 100 & $88 \mathrm{efg}$ \\
& 10,000 & $100 \mathrm{a}$ \\
Taurocholic acid & 1,000 & $100 \mathrm{a}$ \\
& 100 & $99 \mathrm{bc}$ \\
Sodium cholate hydrate & 10,000 & $91 \mathrm{cdefg}$ \\
& 1,000 & $85 \mathrm{fg}$ \\
Sodium laural sarcosine & 100 & $88 \mathrm{efg}$ \\
& 10,000 & $86 \mathrm{fg}$ \\
Cationic & 1,000 & $85 \mathrm{~g}$ \\
Benzalkonium chloride & 100 & $90 \mathrm{defg}$ \\
& 10,000 & $100 \mathrm{a}$ \\
CTAB & 1,000 & $100 \mathrm{a}$ \\
& 100 & $81 \mathrm{efg}$ \\
& 10,000 & $100 \mathrm{a}$ \\
& 1,000 & $100 \mathrm{a}$ \\
Percent & 100 & $100 \mathrm{a}$ \\
& 10,000 & $100 \mathrm{a}$ \\
& 1,000 & $100 \mathrm{a}$ \\
& 100 & \\
& & \\
& &
\end{tabular}

${ }^{y}$ Percent reduction in CFUs compared with the control treatment without surfactant $(n=3)$. Different letters indicate statistically significant differences as determined by Tukey's $w$ test for means separation of ranked data.

${ }^{\mathrm{z}}$ Cetyltrimethylammonium bromide. plants. The first cut in every sequence of cuts developed a gall. The probability of gall development declined with each sequential cut (Fig. 1). The probability of gall formation on D. stramonium declined to $58 \%$ by the third cut and $0 \%$ by the ninth cut. On walnut, the probability of gall formation declined to $51 \%$ by the second cut and $28 \%$ by the last (sixth) cut. For both walnut and D. stramonium, plants cut with a noninoculated blade did not develop galls. Based on the ANOVA, the frequency of gall development produced by using inoculated blades was significantly greater than the frequency of gall development using noninoculated blades $(0 \%)(P<$ 0.0001).

Surfactant evaluation. Overall, A. tumefaciens isolate 186 was significantly more sensitive to cationic surfactants than to anionic or non-ionic surfactants (Table 1). BC and CTAB, the cationic surfactants evaluated, reduced populations of A. tumefaciens by $100 \%$ regardless of whether surfactant was used at $100,1,000$, or $10,000 \mathrm{ppm}$. In contrast, four of the seven anionic and nonionic surfactants evaluated did not reduce populations of $A$. tumefaciens by $100 \%$ even at concentrations of $10,000 \mathrm{ppm}$. Efficacy of the other three anionic and nonionic surfactants (Triton X, sodium dodecyl sulfate, and sodium laurel sarcosine) decreased with decreasing concentration of surfactant. These results led to selection of the cationic surfactants for further testing. $\mathrm{LD}_{100}$ values for $A$. tumefaciens were 7.0, 5.0, 2.0, and $0.5 \mathrm{ppm}$ when exposed to $\mathrm{BC}$, $\mathrm{CTAB}$, Physan, and sodium hypochlorite for $30 \mathrm{~min}$, respectively (Fig. 2).

Effect of cationic surfactant exposure time. The interaction of cationic surfactant treatment $(\mathrm{BC}, \mathrm{CTAB}$, and water control treatment) with duration of exposure was significant $(P<0.0001)$ in the ANOVA for results combined over repeated experiments. Exposure of A. tumefaciens suspensions for $<30 \mathrm{~min}$ to BC and CTAB required significantly greater doses to eliminate $100 \%$ of the $186 \mathrm{r}$ population than exposure to $\mathrm{BC}$ and $\mathrm{CTAB}$ for $>30$ min (Table 2). At $70 \mathrm{ppm}, \mathrm{BC}$ and CTAB eliminated $99 \%$ of the population after $5 \mathrm{~s}$ but up to $30 \mathrm{~s}$ of exposure was required to eliminate $100 \%$ of the bacterial population. Exposure of $1 \mathrm{~s}$ to $\mathrm{BC}$ or CTAB at 100 or $500 \mathrm{ppm}$ eliminated $100 \%$ of the population (Table 2).

Greenhouse cutting tool assay. Trial was not a significant factor in the ANOVA $(P=0.852)$; therefore, data from both trials were pooled. The populations of A. tumefaciens collected in the water

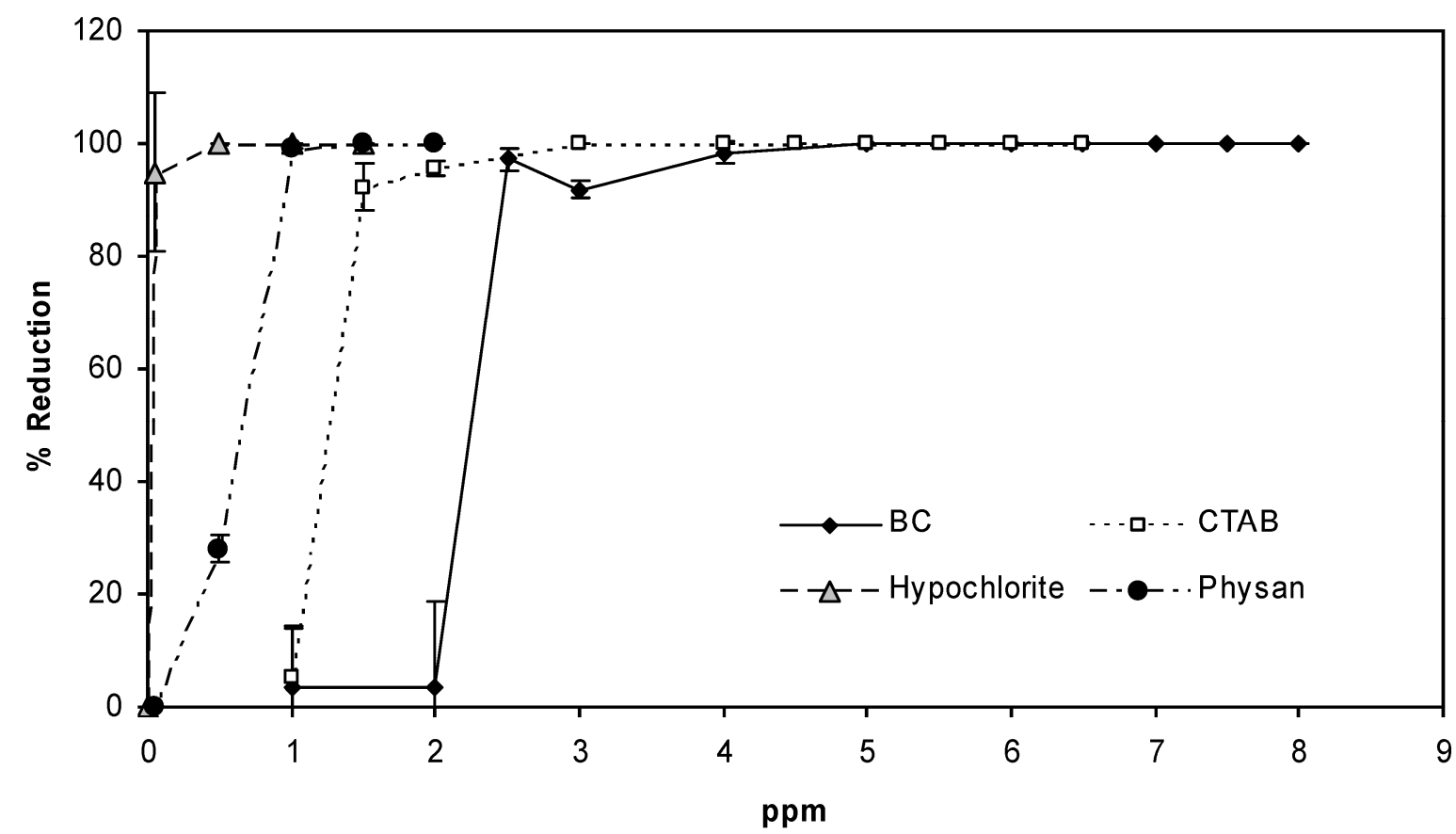

Fig. 2. Dose response curve of Agrobacterium tumefaciens isolate 186 to benzalkonium chloride (BC), cetyltrimethylammonium (CTAB), Physan 20 (Physan), and sodium hypochlorite (hypochlorite) after a 30-min exposure to a given concentration (ppm) of each product. Each data point represents the mean and standard deviation of four replicates of each treatment averaged over each of two experiments. 
used to rinse cutting tools after the blades had been inoculated with the pathogen were significantly greater than populations detected when disinfectant solutions were used on the inoculated blades $(P<0.0001)$. Similarly, there were significantly more galls on plants cut with inoculated blades rinsed in water than on plants cut with inoculated blades rinsed in disinfectant solutions prior to cutting the plants $(P<0.00625)$. A. tumefaciens $186 \mathrm{r}$ was not detected on cutting blades or in the disinfectant solutions when the blades were treated with BC or CTAB for $5 \mathrm{~s}$ at 70 , 100 , or $500 \mathrm{ppm}$. However, galls developed on 8,8 , and $25 \%$ of the $D$. stramonium stems cut with blades treated with these respective concentrations of $\mathrm{BC}$, and 17,17 , and $8 \%$ of the stems cut with blades treated with these respective concentrations of CTAB (Table 3). A. tumefaciens 186r was not detected on cutting blades or in disinfectant solutions when the blades were treated with BC or CTAB for $5 \mathrm{~s}$ at 5,000 ppm and galls did not form on D. stramonium stems cut with the blades treated at this concentration with either disinfectant (Table 3). In contrast, when water was applied to the inoculated blades, 186r populations averaged $9.6 \times 10^{2} \mathrm{CFU} / \mathrm{ml}$ in the wash-water solutions and tumors developed in all of the stem cuts.

Effect of total solids on surfactant efficacy against $A$. tumefaciens. Trial was not a significant factor $(P=0.623)$ in the ANOVA; therefore, data from both trials were pooled. Means separation was determined by Tukey's $w$ test on the pooled data. Suspended solids reduced the efficacy of sodium hypochlorite more significantly than the efficacy of BC, CTAB, or Physan (Table 4). Compared with distilled water with no solids, the efficacy of sodium hypochlorite at $0.02 \mathrm{ppm}$ at killing A. tumefaciens was $64 \%$ less effective in suspensions containing total solids at $0.7 \mathrm{~g} / \mathrm{ml}$. In suspensions containing total solids at $3 \mathrm{~g} / \mathrm{ml}$, the efficacy of sodium hypochlorite at $0.02 \mathrm{ppm}$ was reduced $91 \%$. In suspensions containing total solids at 0.7 or $3.0 \mathrm{~g} / \mathrm{ml}$, the $\mathrm{LD}_{80}$ concentrations of $\mathrm{BC}, \mathrm{CTAB}$, and Physan $(2.5,2.0$, and $0.8 \mathrm{ppm}$, respectively) were reduced by 21,28 , and $31 \%$, respectively.

\section{Discussion}

The walnut hybrid Paradox is the dominant rootstock used in California walnut production (34). The benefits of this rootstock are often outweighed by its susceptibility to A. tumefaciens. Under nursery conditions, we have observed large numbers of grafted Paradox seedlings with galls at the graft union or bleeding wounds, implicating the involvement of improperly sanitized grafting and cutting tools. This study demonstrated it is possible to spread $A$. tumefaciens on contaminated grafting tools onto D. stramonium as well as Paradox walnut seedlings, resulting in crown gall formation. Interestingly, each sequential cut from an inoculated cutting tool resulted in a reduced probability of crown gall developing, most likely due to some of the inoculum being rubbed into the wounds of the previous cuts.

Many nursery operations use disinfectants to clean tools between grafting cuts in order to minimize the spread of phytopathogens. Though highly corrosive, sodium hypochlorite is a common disinfectant used to clean solid surfaces to minimize the spread of pathogens. This disinfectant was effective against $A$. tumefaciens at an $\mathrm{LD}_{100}$ of $0.5 \mathrm{ppm}$ in this study. Unfortunately, the oxidizing potential of sodium hypochlorite is significantly reduced in solutions with suspended and dissolved solids (total solids) $(4,14-$ $16,44)$. In this study, sodium hypochlorite efficacy against $A$. tumefaciens decreased by nearly two-thirds in a suspension with total solids at $0.7 \mathrm{~g} / \mathrm{ml}$ compared with water without solids.

In this study, a class of cationic surfactants known as quaternary ammonium compounds (QACs), which includes BC, CTAB, and Physan, effectively reduced $A$. tumefaciens populations compared with selected anionic and non-ionic surfactants evaluated. Previous studies also reported greater biocidal effects of cationic surfactants compared with anionic and non-ionic surfactants $(26,36)$. At low concentrations, QACs act on membrane permeability and cause cytolytic leakage. At high concentrations, QACs target carboxylic groups and coagulate bacterial cytoplasm (36). BC, CTAB, and Physan, exhibited $\mathrm{LD}_{100}$ concentrations of 7, 5, and $2 \mathrm{ppm}$,

Table 3. Proportion of Datura stramonium stems that developed galls when Agrobacterium tumefaciens-inoculated grafting blades were treated with benzalkonium chloride (BC), cetyltrimethylammonium bromide (CTAB), sterile water (SW), or not treated (negative control) $5 \mathrm{~s}$ prior to wounding the plants with the grafting blade

\begin{tabular}{lcc}
\hline Wash solution & Concentration $(\mathbf{p p m})$ & Stems with galls $(\%)^{\mathbf{y}}$ \\
\hline $\mathrm{BC}$ & 70 & $8 \pm 0.6^{\mathrm{z}}$ \\
& 100 & $8 \pm 1.4^{\mathrm{z}}$ \\
& 500 & $25 \pm 2.4^{\mathrm{z}}$ \\
$\mathrm{CTAB}$ & 5,000 & $0^{\mathrm{z}}$ \\
& 70 & $17 \pm 1.4^{\mathrm{z}}$ \\
& 100 & $17 \pm 2.8^{\mathrm{z}}$ \\
& 500 & $8 \pm 1.4^{\mathrm{z}}$ \\
SW & 5,000 & $0^{\mathrm{z}}$ \\
Negative control & Not applicable & 100 \\
\hline
\end{tabular}

${ }^{y}$ Mean \pm standard deviation of the incidence $(\%)$ of stems on which a crown gall developed.

${ }^{z}$ Significantly different incidence of galls from that of plants treated with sterile water, as determined by $\chi^{2}$ analysis (Bonferroni adjusted significance value of $P \leq 0.00625$ ). Each treatment was replicated six times in two trials. Data from both trials were pooled.

Table 4. Percent reduction in Agrobacterium tumefaciens populations after 30 min exposure to the lethal dose that killed $80 \%$ of the bacterial population in concentrations of sodium hypochlorite, benzalkonium chloride (BC), cetyltrimethylammonium bromide (CTAB), and Physan 20 $(0.02,2.50,2.00$, and $0.80 \mathrm{ppm}$, respectively) prepared in water with various concentrations of total solids ${ }^{\mathrm{z}}$

\begin{tabular}{lcccc}
\hline $\begin{array}{l}\text { Total solids } \\
\text { (g/ml) }\end{array}$ & $\begin{array}{c}\text { Sodium } \\
\text { hypochlorite }\end{array}$ & BC & CTAB & Physan 20 \\
\hline 0 & $93 \mathrm{a}$ & $81 \mathrm{a}$ & $79 \mathrm{a}$ & $83 \mathrm{a}$ \\
0.7 & $29 \mathrm{~b}$ & $67 \mathrm{~b}$ & $63 \mathrm{~b}$ & $74 \mathrm{ab}$ \\
1.5 & $11 \mathrm{c}$ & $65 \mathrm{~b}$ & $59 \mathrm{bc}$ & $67 \mathrm{~b}$ \\
2.0 & $4 \mathrm{c}$ & $63 \mathrm{~b}$ & $54 \mathrm{c}$ & $54 \mathrm{c}$ \\
3.0 & $2 \mathrm{c}$ & $60 \mathrm{~b}$ & $51 \mathrm{c}$ & $52 \mathrm{c}$ \\
\hline
\end{tabular}

${ }^{\mathrm{z}}$ Different letters within a column indicate statistically significant differences as determined by Tukey's $w$ procedure for means separation. Each treatment was replicated three times in two trials. Data from both trials were pooled.

Table 2. Reduction in Agrobacterium tumefaciens populations exposed to benzalkonium chloride (BC) or cetyltrimethylammonium bromide (CTAB) solution

\begin{tabular}{|c|c|c|c|c|c|c|}
\hline \multirow[b]{2}{*}{ Surfactant } & \multirow[b]{2}{*}{ Concentration (ppm) } & \multicolumn{5}{|c|}{ Reduction (\%) per exposure time ${ }^{\mathrm{z}}$} \\
\hline & & $1 \mathrm{~s}$ & $5 \mathrm{~s}$ & $10 \mathrm{~s}$ & $20 \mathrm{~s}$ & $30 \mathrm{~s}$ \\
\hline \multirow[t]{3}{*}{ Benzalkonium chloride } & 70 & $99 \mathrm{~b}$ & $99 \mathrm{~b}$ & $99 \mathrm{~b}$ & $99 \mathrm{~b}$ & $100 \mathrm{a}$ \\
\hline & 100 & $100 \mathrm{a}$ & $100 \mathrm{a}$ & $100 \mathrm{a}$ & $100 \mathrm{a}$ & $100 \mathrm{a}$ \\
\hline & 500 & $100 \mathrm{a}$ & $100 \mathrm{a}$ & $100 \mathrm{a}$ & $100 \mathrm{a}$ & $100 \mathrm{a}$ \\
\hline \multirow[t]{3}{*}{ СТAB } & 70 & $99 \mathrm{~b}$ & $99 \mathrm{~b}$ & $100 \mathrm{a}$ & $100 \mathrm{a}$ & $100 \mathrm{a}$ \\
\hline & 100 & $100 \mathrm{a}$ & $100 \mathrm{a}$ & $100 \mathrm{a}$ & $100 \mathrm{a}$ & $100 \mathrm{a}$ \\
\hline & 500 & $100 \mathrm{a}$ & $100 \mathrm{a}$ & $100 \mathrm{a}$ & $100 \mathrm{a}$ & $100 \mathrm{a}$ \\
\hline
\end{tabular}

${ }^{\text {z }}$ Percent reduction in CFU compared with the control treatment without surfactant. Each treatment was replicated four times in two trials. Data from both trials were pooled. Different letters indicate statistically significant differences as determined by Tukey's $w$ procedure for means separation on ranked data. 
respectively, when A. tumefaciens was exposed to these materials for $30 \mathrm{~min}$.

The efficacy of $\mathrm{BC}$ and $\mathrm{CTAB}$ against $A$. tumefaciens was reduced by only 14 to $16 \%$ in the presence of total solids at $0.7 \mathrm{~g} / \mathrm{ml}$, whereas the efficacy of sodium hypochlorite was reduced by $64 \%$. In the presence of total solids at $3 \mathrm{~g} / \mathrm{ml}$, efficacy was reduced by 21,28 , and $31 \%$ for BC, CTAB, and Physan, respectively, compared with $98 \%$ reduction in efficacy of sodium hypochlorite. The elevated tolerance of QACs to dissolved organic matter, a specific component of total solids, has been reported in studies examining the antimicrobial activities of QACs against foodborne bacteria $(4,14,19,22)$. Given the tolerance of QACs to total solids, QACs are a robust alternative to strong oxidizing agents for surface-sanitizing applications under field situations. Additionally, a study conducted by Luppens et al. (24) reported BC was more efficient than sodium hypochlorite at reducing bacterial populations in biofilms. This quality increases the potential utility of QACs over sodium hypochlorite for many field applications where disinfecting solutions often accumulate high levels of total solids.

Other important attributes to consider when choosing a disinfectant are potential metal-corroding properties and phytotoxic effects. In this study, preliminary observations were noted on the corrosive and phytotoxic characteristics of sodium hypochlorite, Physan, BC, and CTAB. D. stramonium stems cut with blades dipped into solutions of sodium hypochlorite (6 ppm) or Physan (4 ppm) produced abnormal corky tissue around the wounds. In contrast, cuts made with BC- and CTAB-treated blades (3,000 ppm) produced wounds indistinguishable from those on stems cut with blades dipped in water (data not shown). We also observed that stainless-steel blades soaked in sodium hypochlorite $(6 \mathrm{ppm})$ quickly rusted, whereas blades soaked in BC and CTAB (3,000 $\mathrm{ppm}$ ) did not show any rusting after $48 \mathrm{~h}$ (data not shown). The hazards of working with chlorinated compounds also include corrosion of water pipes, yellowing or death of seedlings and mature plants, and production of noxious fumes that can endanger workers $(2,10,44)$. These hazards do not exist when using the cationic surfactants evaluated at the concentrations tested in this study.

Exposure time to a given disinfectant can have a dramatic impact on effectiveness of the disinfectant $(25,36)$. In this study, increased concentrations of $\mathrm{BC}$ and $\mathrm{CTAB}$ were required to eliminate $A$. tumefaciens populations if the duration of exposure of the bacterium to the surfactant was $<30$ min. The $\mathrm{LD}_{100}$ for $\mathrm{BC}$ was 7 ppm when a suspension of A. tumefaciens was exposed for $30 \mathrm{~min}$. The $\mathrm{LD}_{100}$ increased to $70 \mathrm{ppm}$ for $\mathrm{BC}$ when A. tumefaciens was exposed for $30 \mathrm{~s}$. CTAB at $70 \mathrm{ppm}$ required up to $10 \mathrm{~s}$ for elimination of $100 \%$ of A. tumefaciens 186 in an aqueous suspension. Surfactant concentrations greater than $70 \mathrm{ppm}$ were needed to eliminate A. tumefaciens on the surface of cutting blades. Bacteria can be more difficult to eliminate from solid surfaces than in liquid suspensions, because the bacterial cells can be sheltered from sanitizers in protected microscopic environments or in established biofilms on solid surfaces $(5,7)$. In practice, a 5-s dip in BC or $\mathrm{CTAB}$ at 100 or $500 \mathrm{ppm}$ lowered A. tumefaciens populations below detection limits. A 5-s dip in BC or CTAB at 5,000 ppm $(0.5 \%$ solution) was sufficient to prevent gall development on inoculated plants. BC or CTAB at $5,000 \mathrm{ppm}$ also eliminated A. tumefaciens populations in the surfactant solution, which could act as an inoculum reservoir if organic matter concentration increased in the solution or if adequate concentrations of a bactericide were not maintained in the suspension.

Bacteria can develop resistance to many disinfectant products and QACs are no exception $(1,18,35,39,40)$. BC use in the food industry has resulted in development of resistant forms of Pseudomonas spp., Staphylococcus aureus, and Listeria monocytogenes $(1,14,21,23,39,40)$. Isolates of Pseudomonas aeruginosa also have been reported to be tolerant of CTAB (23). For these reasons, prudent measures should be taken to ensure appropriate concentrations of QACs are used in disinfectant solutions in walnut nursery propagation programs. QAC concentrations should be greater than the minimum $\mathrm{LD}_{100}$ to account for decreases in efficacy from unintentional dilution or elevated total solids. Disinfectant solutions should be refreshed as often as feasible to avoid dilution. Finally, disinfectants with different modes of action should be alternated to reduce selection of mutants resistant to any individual disinfectant.

This study indicates A. tumefaciens can be transferred between walnut plants by contaminated grafting tools in a greenhouse setting. QACs, notably $\mathrm{BC}$ and $\mathrm{CTAB}$, dramatically reduced bacterial contamination on cutting blade surfaces which lowered gall formation in test plants and was less phytotoxic than the commonly used microbiocide, sodium hypochlorite. Both QAC compounds are useful additions to sterilization methods used during grafting operations where high levels of total solids are common. Field studies are being conducted to verify these results in a commercial walnut nursery setting.

\section{Acknowledgments}

This work was supported, in part, by the United States Department of Agriculture-Agricultural Research Service CRIS Project 5306-22000-14-00D and the California Department of Food and Agriculture; Fruit Tree, Nut Tree, and Grapevine Improvement Advisory Board. We thank R. M. Davis for critical reading of this manuscript and $\mathrm{L}$. Pearson for her administrative support.

\section{Literature Cited}

1. Adair, F. W., Geftic, S. G., and Gelzer, J. 1969. Resistance of Pseudomonas to quaternary ammonium compounds. Appl. Microbiol. 18:299-302.

2. Agrios, G. N. 2005. Plant Pathology, 5th ed. Elsevier Academic Press, San Diego, CA.

3. Baker, P. J., Coburn, R. A., Genco, R. J., and Evans, R. T. 1978. The in vitro inhibition of microbial growth and plaque formation by surfactant drugs. J. Periodontal Res. 13:474-485.

4. Best, M., Kennedy, M. E., and Coates, F. 1990. Efficacy of a variety of disinfectants against Listeria spp. Appl. Environ. Microbiol. 56:377-380.

5. Brown, M. R. W., and Gilbert, P. 1993. Sensitivity of biofilms to antimicrobial agents. J. Appl. Bacteriol. 74:87S-97S.

6. Chilton, M., Currier, T. C., Farrand, S. K., Bendich, A. J., Gordon, M. P. and Nester, E. W. 1974. Agrobacterium tumefaciens DNA and PS8 bacteriophage DNA not detected in crown gall tumors. Proc. Nat. Acad. Sci. USA 71:3672-3676.

7. Costerton, J. W., Cheng, K. J., Geesey, G. G., Ladd, T. I., Nickel, J. C., Dasgupta, M., and Marrie, T. J. 1987. Bacterial biofilms in nature and disease. Annu. Rev. Microbiol. 41:435-464.

8. Denyer, S. H. 1990. Mechanisms of action of biocides. Int. Biodeter. Biodegrad. 26:89-100.

9. Denyer, S. P. 1995. Mechanisms of action of antimicrobial biocides. Int. Biodeter. Biodegrad. 36:227-245.

10. Dreistadt, S. H. 2001. Integrated Pest Management for Floriculture and Nurseries. Statewide Integrated Pest Management Program Publication 3402. Univ. Calif. Div. Agric. Nat. Resour. Oakland.

11. Flint, M. L., ed. 2003. Integrated Pest Management for Walnuts. Statewide Integrated Pest Management Program Publication 3270. Univ. Calif. Div. Agric. Nat. Resour. Oakland.

12. Gainor, B. J., Hockman, D. E., Anglen, J. O., Christensen, G., and Simpson, W. A. 1997. Benzalkonium chloride: a potential disinfecting irrigation solution. J. Orthop. Trauma 11:121-125.

13. Garvie, E. I., and Clarke, P. M. 1955. The disinfectant properties of quaternary ammonium compounds and sodium hypochlorite: a comparison of results using different test methods. J. Appl. Bacteriol. 18:90-106.

14. Gelinas, P., and Goulet, J. 1983. Neutralization of the activity of eight disinfectants by organic matter. J. Appl. Bacteriol. 54:243-247.

15. Glaze, W. H., and Payton, G. R. 1978. Soluble organic constituents of natural waters and wastewaters before and after chlorination. Pages 1-14 in: Water Chlorination: Environmental Impact and Health Effects, Vol. 2. R. J. Jolley, H. Gorchev, and D. H. Hamilton, Jr., eds. Ann Arbor Science, Ann Arbor, MI.

16. Jolley, R. L., Jones, G., Pitt, W. W., and Thompson J. E. 1978. Chlorination of organics in cooling waters and process effluents. Pages 1-14 in: Water Chlorination: Environmental Impact and Health Effects, Vol. 2. R. J. Jolley, H. Gorchev, and D. H. Hamilton, Jr., eds. Ann Arbor Science, Ann Arbor, MI.

17. Jones, J. B., and Raju, B. C. 1988. Systemic movement of Agrobacterium tumefaciens in symptomless stem tissue of Chrysanthemum morifolium. Plant Dis. 72:51-54.

18. Jones, M. V., Herd, T. M., and Christie, H. J. 1989. Resistance of Pseudomonas aeruginosa to amphoteric and quaternary ammonium biocides. Microbios 58:49-62.

19. Klimek, J. W., and Baily, J. H. 1955. Factors influencing the rate of killing of Escherichia coli exposed to benzalkonium chloride. Appl. Environ. Microbiol. 4:53-59.

20. Krysinski, E. P., Brown, L. J., and Marchisello, T. J. 1992. Effect of clean- 
ers and sanitizers on Listeria monocytogenes attached to product contact surfaces. J. Food Prot. 55:246-251.

21. Langsrud, S., and Sundheim, G. 1997. Factors contributing to the survival of poultry associated Pseudomonas spp. exposed to quaternary ammonium compounds. J. Appl. Microbiol. 82:705-712.

22. Lopes, J. A. 1986. Evaluation of dairy and plant sanitizers against Salmonella typhimurium and Listeria monocytogenes. J. Dairy Sci. 69:2791-2796.

23. Lowbury, E. J. L. 1951. Contamination of cetrimide and other fluids with Pseudomonas pyocyanae. Br. J. Ind. Med. 8:22-25.

24. Luppens, S. B. I., Reij, M. W., van der Heijden, R. W. L., Rombouts, F. M., and Abee, T. 2002. Development of a standard test to assess the resistance of Staphylococcus aureus biofilm cells to disinfectants. Appl. Environ. Microbiol. 68:4194-4200.

25. McDonnell, G., and Russell, A. D., 1999. Antiseptics and disinfectants: activity, action and resistance. Clin. Microbiol. Rev. 12:147-179.

26. Merianos, J. J. 1991. Quaternary ammonium antimicrobial compounds. Pages 225-255 In: Disinfection, Sterilization, and Preservation, 4th ed. S. S. Block, ed. Lea \& Febiger, Malvern, PA.

27. Miller, H. N. 1975. Leaf, stem, crown, and root galls induced in chrysanthemum by Agrobacterium tumefaciens. Phytopathology 65:805-811.

28. Milliken, G. A., and Johnson D. E. 1984. Analysis of Messy Data, Vol. I: Designed Experiments. Van Nostrand Reinhold, New York.

29. Moore, L. W., Bouzar, H., and Burr, T. 2001. Agrobacterium. Pages 17-35 In: Laboratory Guide for the Identification of Plant Pathogenic Bacteria, 3rd ed. N. W. Schaad, J. B. Jones, and W. Chun, ed. American Phytopathological Society, St. Paul, MN.

30. Nielsen, T. H., Christophersen, C., Anthoni, U., and Sorensen, J. 2003. Viscosinamide, a new cyclic depsipeptide with surfactant and antifungal properties produced by Pseudomonas fluorescens DR54. J. Appl. Microbiol. 87:80-90.

31. Ogawa, J. M., and English, H. 1991. Diseases of Temperate Zone Tree Fruit and Nut Crops. Univ. Calif. Div. Agric. Nat. Resour. Publ. 3345, Oakland.

32. Pionnat, S., Keller, H., Hericher, D., Bettachini, A., Dessaux, Y., Nesme, X., and Poncet, C. 1999. Ti plasmids from Agrobacterium characterize rootstock clones that initiated spread of crown gall disease in Mediterranean countries. Appl. Environ. Microbiol. 65:4197-4206.

33. Rajagopal, S., Eis, N., and Nickerson, K. W. 2003. Eight gram negative bacteria are 10,000 times more sensitive to cationic detergents than to anionic detergents. Can. J. Microbiol. 49:775-779.

34. Ramos, D. E., ed. 1998. Walnut Production Manual. Univ. California Div. Agric. Nat. Resour. Publ. 3373, Oakland.

35. Russell, A. D., Hammond, S. A., and Morgan, J. R. 1986. Bacterial resistance to antiseptics and disinfectants. J. Hosp. Infect. 7:213-225.

36. Russell, A. D., Hugo, W. B., and Ayliffe, G. A. J. 1999. Principles and Practices of Disinfection, Preservation, and Sterilization, 3rd ed. Blackwell Science University Press, Cambridge, UK.

37. Stanghellini, M. E., Rasmussen, S. L., Kim, D. H., and Rorabaugh, P. A 1996. Efficacy of nonionic surfactants in the control of zoospore spread of Pythium aphanidermatum in a recirculating hydroponic system. Plant Dis. 80:422-428.

38. Steel, R. G. D., Torrie, J. H., and Dickey, D. A. 1997. Principles and Procedures of Statistics: A Biometrical Approach, 3rd ed. WCB/McGraw-Hill, St. Louis.

39. Szumala, A., and Pernak, J. 1986. The natural and laboratory resistance of gram negative rods to quaternary ammonium chlorides with alkylthiomethyl radical. Pharmazie 41:521.

40. To, M. S., Favrin, S., Romanova, N., and Griffiths, M. W. 2002. Postadaptational resistance to benzalkonium chloride and subsequent physicochemica modifications of Listeria monocytogenes. Appl. Environ. Microbiol. 68:5258-5264.

41. Vieira, D. B., and Carmona-Ribeiro, A. M. 2006. Cationic lipids and surfactants as antifungal agents: mode of action. J. Antimicrob. Chemother. 58:760-767.

42. Wang, L. K., and Peery, G. G. 1975. Disinfection with quaternary ammonium compounds. Water Resour. Bull. 11:919-932.

43. Weisburg, W. G., Barns, S. M., Pelletier, D. A., and Lane, D. J. 1991. 16S ribosomal DNA amplification for phylogenetic study. J. Bacteriol. 173:697703.

44. White, G. C. 1994. Handbook of Chlorination, 3rd ed. Van Nostrand Reichhold Co., New York. 